Note

\section{Biological Reduction of Ferric Iron by Iron- and Sulfur-oxidizing Bacteria}

\author{
Kuniki KINO* and Shoji UsamI \\ Department of Applied Chemistry, Waseda \\ University, Okubo 3-4-1, Shinjuku-ku, \\ Tokyo 160, Japan
}

Received April 7, 1981

The ability of ferric iron reduction has been observed for some fungi and bacteria possessing with the enzyme, nitrate reductase. ${ }^{1)}$ Ottow and Klopotek ${ }^{2)}$ have concluded that iron reduction is an enzymatic process and may be mediated by nitrate reductase. However, Thiobacillus ferrooxidans and Thiobacillus thiooxidans are unable to utilize nitrite salts as a nitrogen source. Therefore it is unlikely that nitrate reductase is involved in ferric iron reduction by iron- and sulfur-oxidizing bacteria. The present paper deals wih the ability of ferric iron reduction by thiobacilli cultures when grown on an elemental sulfur medium.

Acidophilic bacterium strain WU-66B, capable of oxidizing sulfur as well as ferrous iron, was isolated from waste water of Dowa Kosaka Mine, Akita Prefecture, Japan. ${ }^{3)}$ Sulfur-oxidizing bacterium strain WU-79A was isolated from soil at Manza Spa, Japan. ${ }^{4)}$ These strains have been identified as $T$. ferrooxidans and $T$. thiooxidans, respectively, on the basis of biochemical criteria. ${ }^{5}$ )

Microorganisms were cultivated aerobically at $30^{\circ} \mathrm{C}$ in a $500 \mathrm{ml}$ Erlenmeyer flask containing $100 \mathrm{ml}$ of the medium and were shaken at $200 \mathrm{rpm}$ on a rotary shaker-incubator. The composition of the culture medium was as follows (g/liter of distilled water): $\left(\mathrm{NH}_{4}\right)_{2} \mathrm{SO}_{4}, 2.0 ; \mathrm{KH}_{2} \mathrm{PO}_{4}, 3.0$; $\mathrm{MgSO}_{4} \cdot 7 \mathrm{H}_{2} \mathrm{O}, 0.2 ; \mathrm{CaCl}_{2}, 0.25$. The initial $\mathrm{pH}$ was adjusted to 2.5 with $2 \mathrm{~N} \mathrm{H}_{2} \mathrm{SO}_{4}$ for $T$. ferrooxidans, and to 4.0 with $1 \mathrm{~N} \mathrm{HCl}$ for $T$. thiooxidans. Elemental sulfur was added at the level of $10 \mathrm{~g}$ per liter.

The amount of formed sulfate was determined by the titration method of Fritz and Freeland. ${ }^{6)}$ Cell growth was quantified by measuring optical density at $470 \mathrm{~nm}$ (UOD) as described previously. ${ }^{7)}$ Ferric iron reduction was measured by assaying the formation of ferrous iron, using $o$ phenanthroline as a specific reagent. The amount of dissolved ferrous iron was expressed in micromoles of $\mathrm{Fe}^{2+}$ per ml.

The supernatant fraction containing the crude cell-free extract (fraction $\mathrm{S}$ ) and the pellet fraction (fraction $\mathrm{P}$ ) used

* Present address: Technical Research Laboratory, Hofu Plant, Kyowa Hakko Kogyo Co., Ltd., Hofu, Yamaguchi 747, Japan. for determination of enzyme activity of ferric iron reduction were prepared as described previously. ${ }^{8)}$ The enzyme activity of ferric iron reduction was determined by a modification of the $\alpha, \alpha^{\prime}$-dipyridyl method, which was used in the measurement of iron oxidase activity. ${ }^{7}$ After 5minute preincubation of $0.5 \mathrm{ml}$ of cell-free extracts with $1.3 \mathrm{ml}$ of $2.5 \mathrm{~mm}$ citrate- $5 \mathrm{~mm}$ phosphate buffer ( $\mathrm{pH} 5.0$ ), the reaction was initiated by addition of $0.1 \mathrm{ml}$ of $10 \mathrm{~mm}$ $\mathrm{FeCl}_{3} \cdot 6 \mathrm{H}_{2} \mathrm{O}$ acidified to $\mathrm{pH} 2.5$ with $2 \mathrm{~N} \mathrm{H}_{2} \mathrm{SO}_{4}$ and $0.1 \mathrm{ml}$ of $5 \mathrm{~mm}$ ascorbic acid as an electron donor, and incubation was carried out for $15 \mathrm{~min}$ at $30^{\circ} \mathrm{C}$. The reaction was terminated by addition of $2.0 \mathrm{ml}$ of a solution composed of 1 part $1: 10 \mathrm{H}_{2} \mathrm{SO}_{4}, 1$ part $20 \%$ ammonium acetate and 3 parts $0.1 \mathrm{M}$ sodium phosphate. The amount of ferrous iron formed was determined by the $\alpha, \alpha^{\prime}$-dipyridyl method since ferric iron does not interfere with this assay. After adding $1.0 \mathrm{ml}$ of $0.5 \% \alpha, \alpha^{\prime}$-dipyridyl solution, the total volume of the reaction mixture was adjusted to $15 \mathrm{ml}$ with distilled water. After $20 \mathrm{~min}$ in the dark, the reaction mixture was centrifuged at $11,000 \times g$ for $10 \mathrm{~min}$ to eliminate the turbidity caused by the preparation of cell-free extracts. The absorbance was measured at $520 \mathrm{~nm}$. Protein content was determined by the method of Lowry et al. ${ }^{9)}$ using bovine serum albumin as a standard.

It was found that $T$. ferrooxidans and $T$. thiooxidans were able to reduce ferric iron to the ferrous state when aerobically grown on elemental sulfur as an energy source. Figure 1 shows reduction of ferric iron as demonstrated by

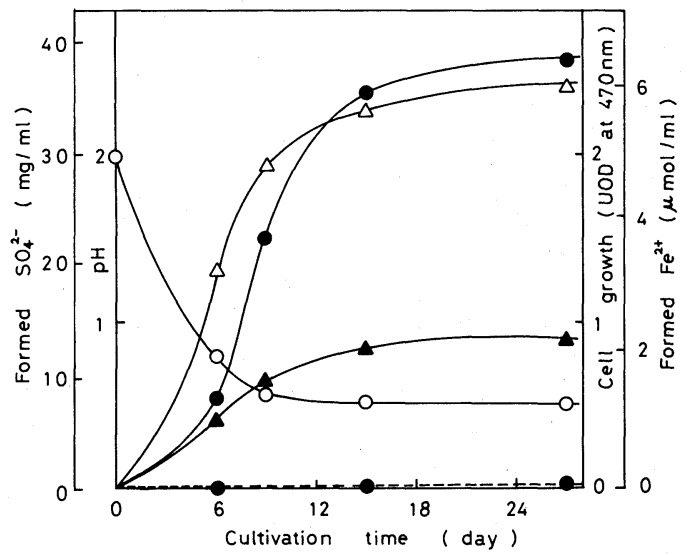

FIG. 1. Reduction of Ferric Iron and Growth of $T$. thiooxidans WU-79A on Elemental Sulfur Medium.

T. thiooxidans was cultivated aerobically at $30^{\circ} \mathrm{C}$ in a $500 \mathrm{ml}$ Erlenmeyer flask containing $100 \mathrm{ml}$ of the medium, ferric chloride was added from a stock solution of $\mathrm{FeCl}_{3} \cdot 6 \mathrm{H}_{2} \mathrm{O}$ to a final concentration of $7.16 \mu \mathrm{mol} \mathrm{Fe}^{3+}$ per $\mathrm{ml}$. Ferric iron reduction was measured by assaying the formation of ferrous iron, using $o$-phenanthroline reagent.

$\mathrm{O}-\mathrm{O}, \mathrm{pH}$ change; $\triangle-\Delta$, formed $\mathrm{SO}_{4}{ }^{2-} ; \boldsymbol{\Delta}-\boldsymbol{\Delta}$, cell growth (UOD); - - formed $\mathrm{Fe}^{2+}$ (inoculated); --- formed $\mathrm{Fe}^{2+}$ (uninoculated). 
Table I. Comparison of the Ability of Ferric Iron Reduction IN $T$. ferrooxidans AND $T$. thiooxidans

Figures show values relative to the $100 \%$ of $T$. thiooxidans after 25 day-cultivation.

\begin{tabular}{lccccc}
\hline Organism & $\begin{array}{c}\text { Cultivation } \\
\text { time (day) }\end{array}$ & $\begin{array}{c}\text { Formed } \mathrm{Fe}^{2+} \\
\left(\Delta \mathrm{Fe}^{2+}\right)\end{array}$ & $\Delta \mathrm{UOD} / \Delta \mathrm{SO}_{4}{ }^{2-}$ & $\Delta \mathrm{Fe}^{2+} / \Delta \mathrm{UOD}$ & $\Delta \mathrm{Fe}^{2+} / \Delta \mathrm{SO}_{4}{ }^{2-}$ \\
\hline & 6 & 8.8 & 105.5 & 16.6 & 10.5 \\
T. ferrooxidans & 9 & 13.3 & 117.6 & 21.0 & 14.5 \\
WU-66B & 15 & 24.2 & 127.4 & 26.9 & 20.0 \\
& 25 & 37.9 & 99.0 & 41.6 & 24.0 \\
T. thiooxidans & 6 & 21.0 & 103.9 & 39.8 & 24.3 \\
WU-79A & 9 & 58.6 & 113.8 & 65.1 & 82.2 \\
& 15 & 92.6 & 107.7 & 91.8 & 10.2 \\
& 25 & 100.0 & 100.0 & 100.0 & 100.0 \\
\hline
\end{tabular}

formation of ferrous iron and the cell growth of $T$. thiooxidans WU-79A. It is obvious that the cell growth, sulfate formation and ferric reduction were essentially parallel throughout the experimental period. At the end of the experiment, virtually all of the ferric iron had been reduced to the ferrous form. No reduction of ferric iron was observed in uninoculated controls even after 25 days of incubation at $30^{\circ} \mathrm{C}$. Although T. ferrooxidans WU-66B adapted to growth on elemental sulfur grew as well as $T$. thiooxidans WU-79A, the ability of iron reduction of WU66B was lower than that of WU-79A (Table I). We discovered that $T$. ferrooxidans grown on an elemental sulfur medium had slight iron oxidase activity. ${ }^{8)}$ On the basis of these facts, it seems likely that in the case of $T$. ferrooxidans the ferrous iron formed by the reduction process might be re-oxidized to ferric iron in the presence of $\mathrm{O}_{2}$, and the ability of reduction was appearently lower than that of T. thiooxidans.

It has generally been assumed that oxidation of sulfide minerals by ferric iron is strictly a nonbiological process. ${ }^{10}$ ) And in the acidic environment where these bacteria occur, ferrous iron formed during the reduction by $T$. thiooxidans may be continually converted to the ferric state by bacteria such as $T$. ferrooxidans. Consequently it is possible that the rate of microbiological leaching of sulfide minerals may be promoted.

Furthermore, it can be considered that ferric iron might serve as an electron acceptor for oxidation of elemental sulfur and that reduction of ferric iron to the ferrous form is consequently detected. However, it is doubtful whether ferric iron can serve as an electron acceptor in respiration when the demand for oxygen exceeds the supply or when oxygen is absent. Nevertheless, Brock and Gustafson ${ }^{11)}$ have reported that anaerobic growth of Thiobacillus cultures using ferric iron are possible. Therefore, we investigated the cell growth and ferric iron reduction of $T$. thiooxidans WU-79A when $\mathrm{N}_{2}$ gas was substituted for $\mathrm{O}_{2}$ in fermentors. As a result, neither ferric iron reduction nor growth could be detected. These results suggested that ferric iron can not serve as an electron acceptor in
TABle II. StOIChiometry of Ferric Iron REDUCTION BY $T$. thiooxidans WU-79A

The complete system contained: $1.3 \mathrm{ml}$ of $2.5 \mathrm{~mm}$ citrate- $5 \mathrm{mM} \mathrm{Na}_{2} \mathrm{HPO}_{4}$ buffer ( $\mathrm{pH} 5.0$ ), $1.0 \mu$ mol ferric chloride, $0.5 \mu \mathrm{mol}$ ascorbic acid, cell-free extract. The amounts of protein used were as follows: supernatant fraction (S), $0.279 \mathrm{mg}$; pellet fraction $(\mathrm{P}), 0.028 \mathrm{mg}$.

\begin{tabular}{ccc}
\hline $\begin{array}{c}\text { Reaction } \\
\text { mixture }\end{array}$ & $\mu \mathrm{mol} \mathrm{Fe}^{2+}$ formed per $15 \mathrm{~min}$ \\
\cline { 2 - 3 } & $\mathrm{S}$ & $\mathrm{P}$ \\
\hline $\begin{array}{c}\text { Complete } \\
\text { Minus cell-free } \\
\text { extracts } \\
\begin{array}{c}\text { Minus ascorbic } \\
\text { acid }\end{array}\end{array}$ & 0.6584 & 0.7366 \\
\hline
\end{tabular}

respiration, and that the reduction will only occur when these bacteria are aerobically grown on elemental sulfur.

It was confirmed that ferric iron reduction was essentially parallel to the cell growth (Fig. 1). Next, we did an experiment to determine whether the reduction was an enzymatic process or not. As shown in Table II, cell-free extracts could not reduce ferric iron to the ferrous state. In the case of deletion of ascorbic acid, the electron donor, the amount of ferrous iron found after 15-minute incubation was not significantly greater than that before incubation.

These results suggested that the reduction of ferric iron by $T$. thiooxidans is a nonenzymatic process, and probably it is dependent on reducing substrates formed during the growth of cells.

\section{REFERENCES}

1) J. C. G. Ottow, Z. Allg. Mikrobiol., 8, 441 (1968).

2) J. C. G. Ottow and A. V. Klopotek, Appl. Microbiol., 18, 41 (1969). 
3) S. Usami and S. Yumimoto, Water Purifn. and Liq. Wastes Treatment (Japan), 11, 17 (1970).

4) T. Sugitani, T. Oneda and S. Usami, Hakko Kyokaishi (Japan), 30, 7 (1970).

5) R. E. Buchanan and N. E. Gibbons, "Bergey's Manual of Determinative Bacteriology," 8th Ed., The Williams and Wilkins Co., Baltimore, 1974, pp. $459 \sim 460$.

6) J. S. Fritz and M. Q. Freeland, Anal. Chem., 26, 1593 (1954).
7) S. Usami, K. Kino, K. Kuroda and N. Sugimoto, Hakkokogaku, 58, 123 (1980).

8) K. Kino, N. Sugimoto and S. Usami, Hakkokogaku, 59, 415 (1981).

9) O. H. Lowry, N. J. Rosebrough, A. L. Farr and R. J. Randall, J. Biol. Chem., 193, 265 (1951).

10) P. C. Singer and W. Stumm, Science, 167, 1121 (1970).

11) T. D. Brock and J. Gustafson, Appl. Environ. Microbiol., 32, 567 (1976). 